NATIONAL RESEARCH UNIVERSITY HIGHER SCHOOL OF ECONOMICS

Boris Sokolov, Eduard Ponarin

\title{
DISILLUSIONMENT AND THE GROWTH OF MASS-LEVEL EUROSCEPTICISM IN POST- COMMUNIST EAST-CENTRAL EUROPE
}

BASIC RESEARCH PROGRAM

WORKING PAPERS

SERIES: SOCIOLOGY

WP BRP 89/SOC/2019 


\section{DISILLUSIONMENT AND THE GROWTH OF MASS-LEVEL EUROSCEPTICISM IN POST-COMMUNIST EAST-CENTRAL EUROPE $^{34}$}

This paper seeks to test if the disillusionment theory developed by Sokolov et al. (2018) to explain the rise of anti-Americanism in post-Soviet Russia, can also explain the recent growth of Euroscepticism in East-Central Europe (ECE). We provide anecdotal evidence of anti-EU disillusionment in the region and then test several empirical implications of the disillusionment theory using mass-level survey data from the European Social Survey (ESS). Our empirical findings are, however, contradictory. This suggests that the disillusionment model cannot be directly applied to the ECE case and should be modified to some extent. We propose two potential modifications. The first is based on David Laitin's concept of "the most favored lords" and the second underscores the benefits that EU membership offers to the upper strata of Eastern European societies.

JEL classification: Y80, Z13

Keywords: East-Central Europe, Euroscepticism, Disillusionment, Democratization

\footnotetext{
${ }^{1}$ Research fellow, Laboratory for Comparative Social Research, National Research University Higher School of Economics. bssokolov@gmail.com

${ }^{2}$ Director, Laboratory for Comparative Social Research, National Research University Higher School of Economics. eponarin13@gmail.com

${ }^{3}$ We thank Margarita Zavadskaya, Hanspeter Kriesi, and participants of the 2019 PONARS Eurasia workshop at St. Petersburg and the regular research seminar at the LCSR HSE for their helpful comments and suggestions. This work is supported by the research grant of the Russian Science Foundation (№19-18-00446 «Societal Foundations of the Conservative Shift in European and Russian Politics: Evidence from the World Values Surveys»).

${ }^{4}$ Replication materials are available from the first author on request
} 


\section{Introduction}

Authoritarian and anti-liberal tendencies in several EU member states from ECE began to attract the attention of political scientists almost immediately after the enlargement of the European Union into the region in the 2000s. In 2007, editors of the Journal of Democracy organized a special symposium devoted to the question of whether democracy was backsliding across ECE (Plattner and Diamond 2007). Most authors invited by the editors to react expressed pessimistic opinions (e.g. Rupnik 2007; Krastev 2007). Since then the situation with democracy in ECE has worsened significantly. As Dawson and Hanley $(2016,22)$ note, almost all countries of the region have fallen spectacularly in the Freedom House rating since the time of EU accession. An important, and worrisome, concomitant of this trend is significant worsening of the relationships between those countries and the EU government and some key EU member states. It is therefore not surprising that the topic became an important research agenda for those studying ECE politics.

This paper deals with one particular aspect of the problem, the rise of an Eurosceptic ideology among the regional elites and general publics (Kopecký and Mudde 2002; Taggart and Szczerbiak 2004; Lubbers and Scheepers 2007; Werts, Scheepers, and Lubbers 2013). Specifically, we suggest that the anti-EU sentiment in new EU member states is driven by a complex ideological phenomenon akin to what Liah Greenfeld, in her book "Nationalism: Five Roads to Modernity", called ressentiment (Greenfeld 1992). We draw our argument on an interpretation of Greenfeld's ideas developed by Sokolov et al. (2018) to explain the rise of anti-American sentiment in Russia. These authors argue that the primary source of Russian anti-Americanism (and, broadly, antiWesternism) is emotional and ideological dissatisfaction with the outcome of pro-Western reforms, which started among the liberal elites in the wake of the perestroika and then spread among the general public.

Though the Russian case is extraordinary, it is structurally similar to what the ECE countries have experienced after the Soviet collapse. In the years that followed the democratic revolutions of the 
late 1980 s and the early 1990 s, all those societies tried to catch up with the Western European states in terms of economic prosperity and political power by adopting political democracy and market economy, but then failed to achieve this goal. This led to frustration of the national elites (who expected more beneficial outcomes of the democratization), and then masses, and gradual disillusionment, or idealistic disappointment with the idea of European integration, and, to some extent, with the liberal political and economic ideologies promoted by the EU. We provide anecdotal evidence of anti-EU ressentiment in the region and then test our conceptual model using mass-level survey data from the ESS.

While we believe that the proposed explanation applies, at least partially, to all EU member states from ECE, we restrict our empirical analysis to the cases of Hungary and Poland, because these two countries are often depicted as exemplary cases of Eurosceptic and authoritarian tendencies in the region. For example, Ivan Krastev describes Poland as "[...] the capital of Central European illiberalism today" (Krastev 2007, 56). In its turn, Hungary is often identified as "[...] the paradigmatic case of (semi-)authoritarian backsliding" in the region (Dawson and Hanley 2016, 23; see also Herman 2016).

Our empirical findings are contradictory. On one hand, we find that disappointment with political and economic condition of one's country is an important predictor of Euroscepticism. Yet, we do not observe the differences in the strength of disillusionment between the elite and the general public that the model of Sokolov et al. predicts. This suggests that this model cannot be directly applied to the ECE case and should be modified to some extent. We propose two potential modifications. The first is based on David Laitin's concept of "the most favored lords" (Laitin 1998) and the second underscores the benefits that EU membership offers to the upper strata of Eastern European societies.

The rest of the paper is organized as follows. In the next section we introduce the concept of ressentiment/disillusionment and outline how it can be utilized to explain the recent anti-EU trend 
in ECE politics. We also provide some anecdotal evidence of elite disillusionment in Hungary and Poland and formulate hypotheses to test in that section. In the third section we describe our data, measurements, and methods. Then we report the results of our empirical analysis. We discuss our findings and limitations of our analysis and make concluding remarks in the final, fifth section.

\section{Theory}

The term ressentiment was coined by Friedrich Nietzsche in his book On the Genealogy of Morality. Liah Greenfeld, a Russia-born American historian, drawing on Max Scheler's reading of Nietzsche, rethought the concept and applied it to the explanation of the origins of nationalist ideologies in European countries in the 18th and the 19th centuries. Greenfeld defines ressentiment as “[...] a psychological state resulting from suppressed feelings of envy and hatred (existential envy) and the impossibility to act them out", which in many cases leads to the "transvaluation of values." (Greenfeld 1992, 15-16). According to Greenfeld, two structural conditions are necessary for the development of this state. The first condition is "[...] the fundamental comparability between the subject and the object of envy, or rather the belief on the part of the subject in the fundamental equality between them, which makes them in principle interchangeable" (Ibid.). The second condition is " [...] the actual inequality (perceived as not fundamental) of such dimensions that it rules the practical achievement of theoretically existing equality out” (Ibid.).

The situation characterized by these conditions is analogous to what Durkheim described as anomie. It often arises when a country attempts to modernize by borrowing institutions and ideologies of another, model country, typically a regional hegemon, and the attempt fails. In this setting, the primary subject of ressentiment is the elite (especially the intellectual elite) of the modernizing country. The import of foreign ideas necessarily implies a focus on the source of importation and comparison with it. However, the model is by definition superior to the imitator in the latter's own perception (Greenfeld 1996, 32). Inevitably, the elite of the modernizing country realizes that their country cannot catch up with the model country. This realization causes 
disappointment with the former ideal and drives the elite toward a nationalist ideology in which the model country (and its institutions and values) becomes an object of hostility and resentment. The elite then propagates this ideology to the mass level and uses it as a powerful tool of political mobilization and national consolidation.

Sokolov et al. (2018) use Greenfeld's theory to explain the rise of anti-Americanism in post-Soviet Russia. It is worth noting that these authors prefer to employ the term disillusionment instead of ressentiment, stressing that the former is more transparent and understandable to the general readership than the latter. In this paper we use both terms interchangeably. These authors show that disappointment with the outcomes of political and economic reforms implemented in Russia in the early post-Soviet period is closely related to anti-American sentiment in the Russian population. Moreover, disappointment in the reforms' outcomes among Russians does not correlate with how they assess the change in their personal economic conditions due to the reforms. Finally. the effect of disappointment on the attitude towards the USA is stronger among highlyeducated people. Sokolov et al. (Ibid., 535) interpret these findings as "[...] evidence of an ideological or idealistic-rather than egoistic or individualistic-reaction to the failed modernization attempt". They conclude that the principal cause of Russian anti-Americanism was "[...] an emotional and ideological dissatisfaction with the outcome of pro-Western reforms that were most intense among those who once idealized America most strongly" (Ibid., 545).

The condition of the ECE countries after the Soviet collapse was similar to that of Russia, and they followed a similar trajectory. The ultimate goal of post-communist modernization in both Russia and ECE was their full integration into Euro-Atlantic structures. In case of Russia, the reform turned out to be a catastrophe and disillusionment was especially severe. Until the mid-2000s the outcomes of democratic transit in ECE was largely perceived by scholars of democratization studies as by far more successful (e.g. King 2000). Most importantly, the regional elites achieved their formal pre-modernization goal: In 2004 eight countries of the region entered the EU, and Romania and Bulgaria joined them in 2007. 
However, the EU accession did not bring the desired level of prosperity into the ECE states. In fact, they did not succeed in their efforts to overtake the West European states. The realization of that disappointing upshot evoked the frustration - not as strong as in Russia, but still visible among the national elites (who expected more beneficial outcomes of the democratization), and masses, and their gradual disillusionment, or idealistic disappointment with the idea of European integration and also with the general liberal ideology promoted by the EU. In the next two subsections we (a) provide some anecdotal evidence of disillusionment among the Eastern European elites and general publics and (b) formulate several implications of our conceptual model that can be tested using mass-level survey data.

\section{Anecdotal evidence}

According to Sokolov et al.'s $(2018,536)$ operationalization, disillusionment is a complex dynamic phenomenon that can be disentangled into three temporarily ordered components, or stages. The constituent feature of the first stage is an expectation, widespread among the elite but also affecting the general public, that adopting institutions of the model country will bring the increase in the political and economic power of their own country. During the second stage, after the implementation of the reform, it becomes clear that the actual outcomes of modernization do not meet the pre-reform expectations, and disappointment with those outcomes gradually comes. As a natural consequence - and it is the third, and final, component - a rapid "U-turn" in the public perception of the model polity occurs, from admiration to hatred.

The first component was undoubtedly observed in ECE before the region became a part of the European Union. First of all, there is a firm consensus in the literature on ECE politics that the regional elites were the main enthusiasts of EU enlargement into the region (Krastev 2007; Herman 2016). There is also evidence of high mass-level EU optimism in the region in that time. During the 2003 wave of European Union membership referendums in Eastern Europe, the pro-accession camp scored an overwhelming victory in all candidate states. As many as $77.3 \%$ in the Czech 
Republic voted for accession; 66.8\% in Estonia; $83.8 \%$ in Hungary; 67.5\% in Latvia; $77.6 \%$ in Poland; $89.6 \%$ in Slovenia; and incredible $91.1 \%$ in Lithuania and $93.7 \%$ in Slovakia. Public opinion polls conducted in the ECE countries in the early 2000s also indicated strong popular support for accession (Kopecký and Mudde 2002, 304-305).

Nevertheless, the goals of the modernization attempt have not been fully achieved and are unlikely to be in the near future. Many authors underscore the instrumental motivation of the ECE elites in their pursuit for the EU membership (Börzel and Risse 2012; Sedelmeier 2014; Dawson and Hanley 2016). The elites in the region were mainly driven by expectations of economic prosperity for their countries and for themselves. But there still is a large, and even increasing, gap in the level of economic development and political influence between the old and the new EU members. In addition, EU accession led to political instability and radicalization of politics in the ECE region (Greskovits 2007), thereby provoking a feeling of insecurity among the ruling elites, challenged by radicals from the right and the left. Taken together, those factors engendered a "transvaluation of values" with respect to the EU among ECE politicians.

A striking example of this dramatic change is the career of Viktor Orban, currently serving as Prime Minister of Hungary, who started as a mainstream liberal and pro-European politician. In the early 1990s, Fidesz, now the most influential Hungarian political party, which Orban was a founder of, declared the integration of Hungary into the EU structures as its primary foreign policy objective (Batory 2002, 533). During his first term as Prime Minister (1998-2002), Orban even allowed himself to criticize EU officials for the lack of speed of the EU accession process (Kopecký and Mudde 2002, 307). But then his ideological position changed significantly, and now he is considered by many as the most authoritarian politician and the main Euroscepticist of ECE.

Figure 1 about here 
The evolution of Orban's views seems to represent the model case of individual ressentiment among members of the ECE ruling class ${ }^{5}$, but definitely not the only one. Another piece of evidence that suggests that the attitudes towards EU have indeed changed among the ECE elites after the 2004 and 2007 EU enlargements, comes from their electoral rhetoric. Our analysis of the Comparative Manifesto Project data for Hungary and Poland shows that party programs gradually drifted to more Eurosceptic positions in those two countries after they acquired EU membership (see Figure 1). Through 1990s, in both countries the share of negative mentions of the EU compared to the share of all mentions of the EU in party manifestos was less than $10 \%$. In early 2000s, immediately before EU accession, it surged up to $20 \%$ in Hungary and to $41.4 \%$ in Poland, but this can be explained simply by a moment-related articulation of the question whether to enter the EU or not in national political debates, and also by the annoyance of the ECE elites with the delay with accession (e.g. Pridham 2006). In the late 2000s and early 2010s, the level of partylevel Euroscepticism gradually grew in both countries, reaching the $30 \%$ mark at the last available data point (April 2014 for Hungary and October 2011 for Poland). The change of ECE parties' rhetoric towards Eurosceptic positions immediately before and in the wake of EU accession also did not come unnoticed by other students of the topic (Kopecký and Mudde 2002; Batory 2002; Taggart and Szczerbiak 2004).

\section{Hypotheses}

The disillusionment theory implies several propositions that can be tested using mass-level survey data. First, it predicts that the attitude towards the model country (or, as with the EU, a supranational unit) should correlate negatively with individual disappointment or dissatisfaction with his/her own country's current condition. However, disappointment in a country's condition obviously is a quite multifaceted concept. When an individual says, using general wording, that she/he is disappointed with the condition of her/his country, it is not clear which particular

\footnotetext{
${ }^{5}$ This claim may be seen as too strong, since a change in the public rhetoric of a politician does not necessarily reflect an actual change in her/his mind.
} 
component of disappointment is emphasized: That country's politics, state of economy or culture, or even poor personal circumstances that bias an individual perception of what is going on with the country as a whole. In contrast, the notion of disillusionment suggests that what matters is the idealistic disappointment in how effective and powerful the country, as a political body, is, and not personal dissatisfaction with poor material conditions. Therefore, we hypothesize that

H1: There is a negative association between the attitude towards the EU and the level of satisfaction with how well the political system and economy of one's country are functioning.

H2: The strength of correlation between the attitude towards the EU and the level of satisfaction with one's country's condition should be larger, in absolute terms, than the strength of correlation between the attitude towards the EU and the level of satisfaction with one's individual life conditions.

Second, disillusionment is an elite-driven phenomenon. Moreover, it emerges first of all among the intellectual elite that initially defines the ultimate goals of the reform for the whole nation and then evaluates the results. The evaluation is typically being done against a hugely inflated benchmark, which naturally causes disappointment in the outcomes of the modernization attempt. According to this reasoning, the signs of disillusionment should be the most explicit among the educated segment of the ECE societies affected by ressentiment. Hence, we predict that

H3: The correlation between the attitude towards the EU and the level of satisfaction with the current condition of one's country should increase, in absolute terms, with one's level of education.

As with the bivariate association between Euroscepticism and disappointment, it is important to distinguish between different shades of disappointment with respect to the conditional hypothesis above. This intuition leads us to the following claim: 
H4: The interplay between one's educational attainment and disappointment must be stronger for political and economic disappointment than for general disappointment with life.

Our third group of predictions adds a dynamic component to our framework and reflect the fact that disillusionment is not a constant feature of public opinion in a contaminated country. It arises when a country attempts to modernize and fails. As a consequence, one should not observe any evidence of disillusionment before the modernization attempt has started.

H5: The correlation between the attitude towards the EU and dissatisfaction should be absent before EU accession

H6: The interplay between one's educational attainment and disappointment should be absent, or at least weaker, before EU accession.

Finally, the notion of disillusionment has also several corollaries that can be visible only at the aggregate level. Disillusionment is a form of reaction to institutional change, so it must follow the reform, possibly with some lag, and not precede it. And, as with individual-level hypotheses, it is important to underscore that the political component of dissatisfaction also plays the central role in the aggregate-level incarnation of disillusionment. This means that:

H7: The aggregate level of dissatisfaction in a country should increase after the acquisition of EU membership.

H8: The aggregate level of Euroscepticism in a country should increase after the acquisition of EU membership.

H9: The aggregate level of political and economic dissatisfaction after the acquisition of EU membership should be higher than the aggregate level of dissatisfaction with life. 


\section{Data and Methods}

We provided some anecdotal evidence of disillusionment among the ECE political class above. To test whether the elite's disillusionment is accompanied by mass-level disillusionment, we use data for Poland and Hungary from the European Social Survey (ESS). The ESS is a biannual survey project that provides high-quality data on a broad set of socio-political views and opinions of the European population. The project started in 2002, and since that eight rounds of representative national surveys, covering most European societies, have been released. The timing of the ESS perfectly fits the goals of the present study, since it includes the period immediately before Poland and Hungary entered the European Union (both countries become EU member states on 1 May of 2004) and all years of their membership in the EU, thus allowing for the comparison of attitudes of the citizens of the two countries before and after the institutional change. Data and documentation for all ESS rounds are freely available at https://www.europeansocialsurvey.org/.

The standard ESS questionnaire offers two questions about individual attitudes towards the EU. The first question (labelled in the ESS codebook as trstep) measures the level of individual trust to the European Parliament. The answers to this question are recorded on a $0-10$ scale on which 0 means "no trust at all", and 10 means "complete trust". The second question (euftf) also represents a 0-10 scale. It reflects individual opinions about whether European unification should go further (which corresponds to 10) or it has already gone too far (corresponds to 0). Using the second item for our purposes may be somewhat problematic, since it was not included in the questionnaire of the first (and also the fifth) ESS round for the countries of our interest, and it is thus not possible to compare the pre-accession attitudes towards European integration to the post-accession attitudes. Still, we believe that it is important to use all available information. In addition, all our hypotheses that have a temporal component admit that the predicted public opinion change might occur with some lag, therefore it should still be visible in a long-run perspective, even if the measurements for the starting point are missing. 
The overlap between the two measures of Euroscepticism is not particularly strong: they correlate only at 0.26 (Pearson's rho; $p$-value $=0.000)$. This suggests that these items reflect different shades of Euroscepticism/optimism. Conceptually, the first item can be interpreted as a measure of the attitude towards the EU as it exists and operates now and the second item may be interpreted as a measure of the attitude towards EU as an "ideal" project (van Elsas, Hakhverdian, and van der Brug 2016; Hobolt and de Vries 2016; Kopecký and Mudde 2002)

To measure political disappointment, we use two ESS questions (stfdem and stfgov), asking respectively (1) how satisfied are respondents with the way democracy works in their country and (2) how satisfied are they with the way their national government is doing its job. Since "democracy" is a more abstract concept than "national government", we believe that the first item can be interpreted a more idealistically loaded indicator of political dissatisfaction, and the second item should be seen as a more practically oriented one. To measure economic disappointment, we use the ESS question (stfeco) asking respondents how satisfied are they with the present state of the economy in their countries.

All these items utilize a 0-10 scale where 0 means "extremely dissatisfied" and 10 means "extremely satisfied". Notice that we recode all these variables in the reverse order, thereby making them to be the measures of dissatisfaction, and not satisfaction. These three variables correlate quite strongly with each other: the correlation (Pearson's rho) between the two measures of political disappointment is $0.66(\mathrm{p}$-value $=0.000)$, and the correlations between economic dissatisfaction and the two former variables are $0.58(\mathrm{p}$-value $=0.000)$ and $0.62(\mathrm{p}$-value $=0.000)$ respectively. We therefore combine these measures into a single composite index of dissatisfaction.

The fourth variable from the ESS dissatisfaction battery that we use in our analysis measures general dissatisfaction with life as a whole (stflife; also 0-10 scale) and therefore serves as a proxy of dissatisfaction with the individual, rather than national, condition. This variable correlates only 
moderately with the indicators of political and economic dissatisfaction (respective Pearson's rhos are $0.31,0.25$, and 0.40 ; all p-values $=0.000)$, which suggests that dissatisfaction with one's country's condition does not have much in common with dissatisfaction with one's own condition and may be interpreted as a manifestation of ideational, rather than material, disappointment.

To approximate the (intellectual) elite status, we use individual responses to the following ESS question (edulvla $)^{6}:$ "What is the highest level of education you have achieved?". Originally, this variable has five categories: "Less than lower secondary", "Lower secondary", "Upper secondary", "Post-secondary non-tertiary", "Tertiary". We dichotomize this variable by juxtaposing those with tertiary education completed to all other respondents, for two reasons. The first is a low frequency of respondents belonging to intermediate (second and fourth) categories. The second, and more important, is the fact that the notion of disillusionment, as was multiple times noted above, emphasizes the contrast between exquisite and clear aspirations of the educated elite and liquid and coarse emotions of the masses, therefore within-mass level variation in educational attainment is not of primary interest in this context. We nevertheless use the number of years spent on education as an alternative secondary proxy for the intellectual elite status, but this do not alter our main conclusions (see Figures S1-S4 in the Supplemental Information).

Regarding statistical modeling, we employ a conventional OLS setup that includes either of the two measures of Euroscepticism/optimism as dependent variable and the measures of dissatisfaction and education attainment and the interaction between them as independent variables. Importantly, the concept of disillusionment, in a cross-sectional perspective, does not suggest a causal relationship between the level of satisfaction with the home country's condition and the attitude towards the EU. It is true that, according to the ressentiment theory, dissatisfaction should arise first in the minds of affected individuals and then entails the attitudinal change.

\footnotetext{
${ }^{6}$ It is worth noting that in the post-communist context higher education is probably the best available mass-level proxy for the elite status, even regardless of its intellectual component. As Sokolov et al. (2018, 539-540), with a reference to Gerber and Hout (1995, 649), note, education was the most effective channel of upward mobility in communist regimes, so members of the elite had (and still have) strong incentives to secure university education for their children.
} 
However, once developed, both attitudes then coexist and, when being observed simultaneously, turn to be just different indications of a deeper core feeling, namely disillusionment. Thus, we do not assume that the regression coefficients in our models have a causal interpretation. What is important in this respect is only the absence or presence of interrelations between key variables (reflected in statistical in/significance of the respective estimates).

Furthermore, we do not include control variables (except dummies for ESS rounds) in our regression models, because of (a) their potentially biasing effect on standard errors (Clarke 2005) and (b) the possibility of bias in the estimates of key coefficients of interest due to hidden interactions between controls and unobserved confounders (Clarke, Kenkel, and Rueda 2018). We nevertheless check the robustness of our main findings controlling for several conventional sociodemographic and political variables, such as gender, age, employment status and political ideology (see Table S3 in the SI), and find no noteworthy differences. Descriptive statistics for all variables used in the main analysis and supplementary robustness checks are reported in Table S1 in the Supplemental Information.

\section{Results}

For ease of exposition, we test our hypotheses in the reverse order, starting at the aggregate level and then moving to the individual level. We begin our analysis by exploration of temporal trends in the attitudes towards the EU and political, economic, and general dissatisfaction in two countries. Those trends are presented in Figures 2 (EU attitudes) and 3 (dissatisfaction) and to some extent support our aggregate-level hypotheses. Both the level of trust in the European Parliament and the level of support for further EU unification gradually came down in Hungary and Poland in the years that followed the 2004 EU enlargement. In both countries the descending trend is the same for the elite and the general public. However, in contrast to our conjecture, the elite in both countries shows a slightly more pro-European position on both attitudes. 
As to dissatisfaction, the picture is more nuanced. In Hungary, the level of political and economic dissatisfaction started growing after EU accession and grew rapidly until the economic crisis of 2008-2009. For example, the country mean score on the index of political and economic dissatisfaction increased from 5.5 among masses and 4.92 among elites in 2002 to more than 7.80 and 7.62 respectively 2008, by about $50 \%$ for each stratum. However, in 2010 political-economic dissatisfaction returned to the pre-accession level and then remained relatively stable. The average level of general dissatisfaction with life in that country was smaller than for political-economic dissatisfaction in all ESS rounds. In Poland, the level of political-economic disappointment was slightly decreasing in the post-accession years (from 6.72 among masses and 6.48 among elites in 2002 to 5.39/5.65 in 2016), and the level of dissatisfaction with life as a whole was always small (4.23/3.65 in 2002 and 2.93/2.54 in 2016). Again, contrary to what was predicted, the elite generally demonstrates the lower level of dissatisfaction than the general public.

Next, we run our regression models. Figure 4 shows the results for Hungary and Figure 5 shows the results for Poland. In both countries, the effect of all types of dissatisfaction on both types of attitudes towards the EU is negative, as predicted. Then, since both DV and all dissatisfaction indicators are measured on the same scale, the sizes of the respective estimates are roughly comparable. In accord with our expectations political-economic disappointment is a quite strong predictor of (dis-)trust in the European Parliament (for the category "uneducated"7,$\beta=-0.449$ in Hungary and -0.495 in Poland; see Table S1 in the SI) and the attitude towards further EU unification $(\beta=-0.135 /-0.205)$. The effect of dissatisfaction with life on both DV is approximately two times lower in both countries $(\beta=-0.201 /-0.160$ for the first DV and $\beta=-$ $0.085 /-0.105$ for the second DV).

Figures 4 and 5 about here

\footnotetext{
7 Notice that in models with interactive terms the coefficients for constitutive terms show their marginal effects for the case when another interacting variable is equal to zero (Brambor, Clark, and Golder 2006). Thus, in this case all dissatisfaction effects are shown for the group "uneducated". To get the estimates for the group "educated" one should sum up the estimates for the group "educated" and for the interaction term.
} 
Regarding the interaction between dissatisfaction and education ${ }^{8}$, it is insignificant for dissatisfaction with life, for both DVs and in both countries, which agrees with the disillusionment theory. Political-economic dissatisfaction interacts significantly with education in Hungary, but not in Poland. In Hungary, when the level of both types of political dissatisfaction and of economic dissatisfaction is at its lowest, there are only very small and statistically trivial differences between uneducated and educated people in both the level of trust in the European Parliament and the level of support for further EU unification. When political-economic dissatisfaction is at its highest, those differences become sizeable: for both DVs, dissatisfied respondents with higher education are, on average, by approximately one point on a 0-10 scale more pro-European than dissatisfied respondents without higher education (see Figure 3 and Table S2 in the SI). This observation clashes with our key intuition that the effect of dissatisfaction should be most pronounced among the educated "elite". In fact, in Hungary this effect is weaker in the educated stratum. The data from Poland also do not support our conditional hypotheses, since in that country we see no differences in the effect of dissatisfaction between educated and uneducated respondents.

The final set of our empirical tests deals with the dynamics of the two- and three-way associations between the EU attitudes, various types of dissatisfaction, and education. The results of those tests are shown in Figures 6 and 7. Figure 6 reports the regression coefficients for two types of dissatisfaction $^{9}$ and their interactions with education from round-specific models for two countries, with trust in the European Parliament as dependent variable. One can observe a small increase in the main effect of political-economic dissatisfaction on trust in the EP immediately after EU $\operatorname{accession}^{10}$, from -0.546 in 2002 to -0.659 in 2004 in Hungary and from -0.518 in 2002 to 0.587 in 2004 in Poland. Then the effect of this type of dissatisfaction notably decreases in

\footnotetext{
${ }^{8}$ Notice that through this section we assume that the interactions between all types of dissatisfaction and education are linear effects. We checked the linearity assumption using tools proposed in Hainmueller, Mummolo, and Xu (2019) and found that it was plausible in most reported models.

${ }^{9}$ Again, these effect sizes are for the group "uneducated". To get the estimates for the group "educated" one should sum up the estimates for the group "educated" and for the interaction term.

${ }^{10}$ In the 2004 ESS round, fieldwork was done in Hungary in April and May of 2005 and in Poland in the end of 2004 (OctoberDecember). See for details https://www.europeansocialsurvey.org/data/deviations_2.html.
} 
Hungary, though in Poland the effects of both indicators of political dissatisfaction in most postaccession rounds (except 2006 and 2016) are by 10-25\% stronger than in the 2002 round. As to the magnitude of the effect of dissatisfaction with life, in both countries and in all but one rounds it is two to three times lower than the effect of political-economic dissatisfaction. In its turn, the interactions between either type of dissatisfaction and education are significant only in few rounds (and have an opposite sign to what has been expected) in Hungary and insignificant at all in Poland.

\section{Figures 6 and 7 about here}

Figure 7 is similar in its content to Figure 6 with the only exception that the dependent variable in all reported models is the attitude towards further European integration. Also, in this case we do not have a pre-accession benchmark since this question was omitted in the national questionnaires for Hungary and Poland in the 2002 ESS round. Substantively, the results reported in this figure also similar to those in Figure 6. In Hungary, the effect of political-economic dissatisfaction is two to three stronger than the effect of general dissatisfaction, and decreases with time. In Poland, the effect of political-economic disappointment is much stronger than the effect of general dissatisfaction as well, but remains relatively stable during the post-accession period, except the last, 2016 round (data for 2010 are missing). The round-specific interactions between all types of dissatisfaction and education are mostly insignificant.

\section{Discussion and Concluding Remarks}

We want to preface our concluding remarks by an important disclaimer: This study is not intended to be a full-depth investigation of why Eurosceptic forces are on the rise in nowadays Poland and Hungary. Nor it is a fair test of the disillusionment theory against other theories explaining the roots of conservative turn in the region. Its only purpose is to check whether the notion of disillusionment, which proved its fruitfulness with respect to the explanation of the sources of antiWesternism in Post-Soviet Russia, may be also useful for getting a more precise understanding of tectonic ideological processes shaping ECE politics in 2000s and 2010s. 
With respect to this goal, we must conclude that the disillusionment theory finds only very limited support in the ESS data. The mass-level support for the EU has indeed been decreasing in Hungary and Poland since those countries joined the EU. There is also some evidence that immediately after Hungary had entered the EU, the level of political-economic dissatisfaction, but not of general dissatisfaction with life, grew among Hungarians. This however is not true for Poland, where the level of political-economic dissatisfaction after it joined the EU was either at roughly the same rate or even lower than before. In addition, in Hungary itself the level of political-economic dissatisfaction dropped after 2010. Yet, this trend can be a side effect of the recovery after the 2008/09 economic crisis, unrelated to the EU accession itself. Finally, contrary to our surmises, both Euroscepticism and dissatisfaction are less widespread among the educated people in the ECE region. At the individual level, our analysis confirms that political-economic dissatisfaction is an important predictor of Euroscepticism and is stronger related to the EU attitudes than dissatisfaction with individual circumstances. Yet, all our conditional hypotheses are to be rejected. We also do not observe the predicted temporal variation in the nature of the three-way relationship between the EU attitudes, dissatisfaction, and education.

Before we proceed with interpretation of these results, several important limitations of this research are worth mentioning. The ESS is not a panel study and therefore does not allow for tracing individual feelings in a long-run perspective. Moreover, the ESS questionnaire does not include questions suggesting a retrospective comparison of the present and the past of one's country. Therefore, our operationalization of dissatisfaction lacks a temporal, retrospective component, which is essential for the phenomenon of disillusionment (which arises when people initially expect some beneficial outcomes from the reform and only then gradually become disappointed). In addition, our proxy for the elite status, one's educational attainment, is far from being perfect (though hardly can be outperformed by any other variable available at the mass level). It may be the case that we simply are not able to detect true disillusionment because we cannot reach the true elite using ESS data and instead analyze the attitudes of the middle and the 
upper-middle class. On the other hand, the ressentiment theory emphasizes the role of disappointment among the narrow highly-educated stratum of society, and in this respect our measure allows to distinguish between the uneducated masses ( $83.2 \%$ of the pooled sample) and the educated elite ( $16.8 \%$ of the pooled sample).

Methodological and data restrictions aside, several substantive explanations for our findings can be proposed. The first is based on the "Most Favored Lord Status" model proposed by David Laitin. Laitin theorizes that empires, when deciding how to control newly obtained territories, should choose between two main strategies of incorporation of the local elites: colonial-style exclusive incorporation and bargained elite incorporation. In the former case, the elites of the "conquered" areas continue to rule locally but are denied career opportunities at the imperial center. In the latter scenario, the local elites may use various channels of social mobility beyond their territories. This difference has important implications for long-term integration of new territories with the larger polity. A glass ceiling preventing career chances at the imperial center does not motivate the local elite to integrate with the larger state. Consequently, they will try and secede when a political opportunity arises because it is better to be number one in a village than number two in Rome. On the contrary, the "most favored lords" will eventually assimilate and will lead their people to assimilation (Laitin 1998, 60-61).

Applying this framework to the post-communist states case, one may argue that the first approach was used by the "global" West for Russia and the second approach was used by the EU for Eastern European states. In contrast to the Russian political elite, which had not been integrated in the Euro-Atlantic "high society" despite its effort to modernize Russia in the years that followed the perestroika, ECE politicians became full members of the EU political class. For instance, Donald Tusk, one of the leading Polish politicians who served as Prime Minister of Poland for seven years and also is a chairman of the Civic Platform, most influential Polish party, even became the President of the European Council in 2014. Thus, the ECE elites, while presumably being dissatisfied with the outcomes of EU accession for their countries, still have a wide spectrum of 
career opportunities for themselves, which mitigates their disillusionment to some extent. This antidote to disappointment in the EU membership is however absent at the mass level. As a result, masses in the region are more Eurosceptic than the elites and probably force the latter to frame their rhetoric in a somewhat, and sometimes highly, anti-EU fashion, in order to be able to win national elections and secure their positions.

Another explanation of our findings is also centered on the benefits which the EU membership offers to the elites of the new member states, although here we understand the term "elite" in a broader sense compared to that employed in the "most favored lords" explanation. Specifically, by "elite" we now mean not a very small group of high-level national officials and leading politicians but a relatively large fraction of population that includes both the elite in a stricter sense and the highly-educated individuals belonging to the upper-middle class. We already noted above that the latter definition may better match our data and the disillusionment theory. But even defined in an inclusive way, the elite still seems to be a beneficiary of the European integration. Highlyeducated people are in a better position in the unified European labor market and therefore may expect higher income and better overall life chances in the united Europe. In other words, if they follow the logic of what Hooghe and Marks (2005) called the economic calculus theory of EU support, they have quite rational incentives (a) to hold a more positive view of the European Union and (b) to be less dissatisfied with the outcomes of the EU membership for their countries than their less-educated compatriots.

Either of these explanations being true, both suggest a quite pessimistic account of the current political landscape in the new EU member states from ECE. In any case we deal with the masses disappointed to a large extent in both the current state of affairs in the European Union and the very idea of the united Europe, and the opportunistic elite motivated to play the game of the European integration only by its own narrow egoistic interests and not especially committed to the normative ideals of the European project. 
Furthermore, we cannot completely rule out the possibility that disillusionment indeed took place in the region. Although the mass-level data do not fully support and even contradict this possibility in several respects, our anecdotal evidence suggests that the top-level politicians of the region seem to express thoughts and opinions that can be interpreted as signs of ressentiment. If it is indeed so, the situation becomes even worse. In addition to the absence of intrinsic motivation to adhere to the idea of the united democratic Europe, the regional elites may be frustrated by the outcomes of their efforts to modernize their countries and therefore deeply disappointed in that idea. Taken together, all these reasons lead to a mournful conclusion that the anti-European and anti-liberal turn in ECE politics is not just a provisional retreat of democracy but grounds on the particularly acute resonance of the elite's rational incentives with well-entrenched mass frustration.

\section{References}

Börzel, T. A., \& Risse, T. (2012). When Europeanisation meets diffusion: Exploring new territory. West European Politics, 35(1), 192-207.

Brambor, T., Clark, W. R., \& Golder, M. (2006). Understanding interaction models: Improving empirical analyses. Political Analysis, 14(1), 63-82.

Clarke, K. A. (2005). The phantom menace: Omitted variable bias in econometric research. Conflict Management and Peace Science, 22(4), 341-352.

Clarke, K. A., Kenkel, B., \& Rueda, M. R. (2018). Omitted variables, countervailing effects, and the possibility of overadjustment. Political Science Research and Methods, 6(2), 343-354.

Dawson, J., \& Hanley, S. (2016). The Fading Mirage of the" Liberal Consensus". Journal of Democracy, 27(1), 20-34.

Gerber, T. P., \& Hout, M. (1995). Educational stratification in Russia during the Soviet period. American Journal of Sociology, 101(3), 611-660. 
Greenfeld, L. (1990). The formation of the Russian national identity: the role of status insecurity and ressentiment. Comparative Studies in Society and History, 32(3), 549-591.

Greenfeld, L. (1992). Nationalism: Five Roads to Modernity. Cambridge, MA: Harvard University Press.

Greenfeld, L. (1996). Nationalism and modernity. Social Research, 63(1), 3-40.

Greskovits, B. (2007). Economic woes and political disaffection. Journal of Democracy, 18(4), 40-46.

Hainmueller, J., Mummolo, J., \& Xu, Y. (2019). How much should we trust estimates from multiplicative interaction models? Simple tools to improve empirical practice. Political Analysis, 27(2), 163-192.

Herman, L. E. (2016). Re-evaluating the post-communist success story: party elite loyalty, citizen mobilization and the erosion of Hungarian democracy. European Political Science Review, 8(2), 251-284.

Hobolt, S. B., \& De Vries, C. E. (2016). Public support for European integration. Annual Review of Political Science, 19, 413-432.

Hooghe, L., \& Marks, G. (2005). Calculation, Community and Cues. European Union Politics, 6(4), 419-443.

King, C. (2000). Post-postcommunism: transition, comparison, and the end of "Eastern Europe". World Politics, 53(1), 143-172.

Kopecký, P., \& Mudde, C. (2002). The two sides of Euroscepticism: party positions on European integration in East Central Europe. European Union Politics, 3(3), 297-326.

Krastev, I. (2007). The strange death of the liberal consensus. Journal of Democracy, 18(4), 5663. 
Laitin, D. D. (1998). Identity in formation: The Russian-speaking populations in the near abroad. Cornell University Press.

Plattner, M. F., \& Diamond, L. J. (2007). Is East-Central Europe Backsliding? Journal of Democracy, 18(4), 5-6.

Pridham, G. (2006). European Union Accession Dynamics and Democratization in Central and Eastern Europe: Past and Future Perspectives1. Government and Opposition, 41(3), 373-400.

Rupnik, J. (2007). From democracy fatigue to populist backlash. Journal of Democracy, 18(4): $17-25$.

Sedelmeier, U. (2014). Anchoring Democracy from Above? The European Union and Democratic Backsliding in Hungary and Romania after Accession. Journal of Common Market Studies, 52(1), 105-121.

Sokolov, B., Inglehart, R. F., Ponarin, E., Vartanova, I., \& Zimmerman, W. (2018). Disillusionment and Anti-Americanism in Russia: From Pro-American to Anti-American Attitudes, 1993-2009. International Studies Quarterly, 62(3), 534-547.

Taggart, P., \& Szczerbiak, A. (2004). Contemporary Euroscepticism in the party systems of the European Union candidate states of Central and Eastern Europe. European Journal of Political Research, 43(1), 1-27.

Van Elsas, E. J., Hakhverdian, A., \& van der Brug, W. (2016). United against a common foe? The nature and origins of Euroscepticism among left-wing and right-wing citizens. West European Politics, 39(6), 1181-1204.

Werts, H., Scheepers, P., \& Lubbers, M. (2013). Euro-skepticism and radical right-wing voting in Europe, 2002-2008: Social cleavages, socio-political attitudes and contextual characteristics determining voting for the radical right. European Union Politics, 14(2), 183-205. 


\section{Figures and Tables}

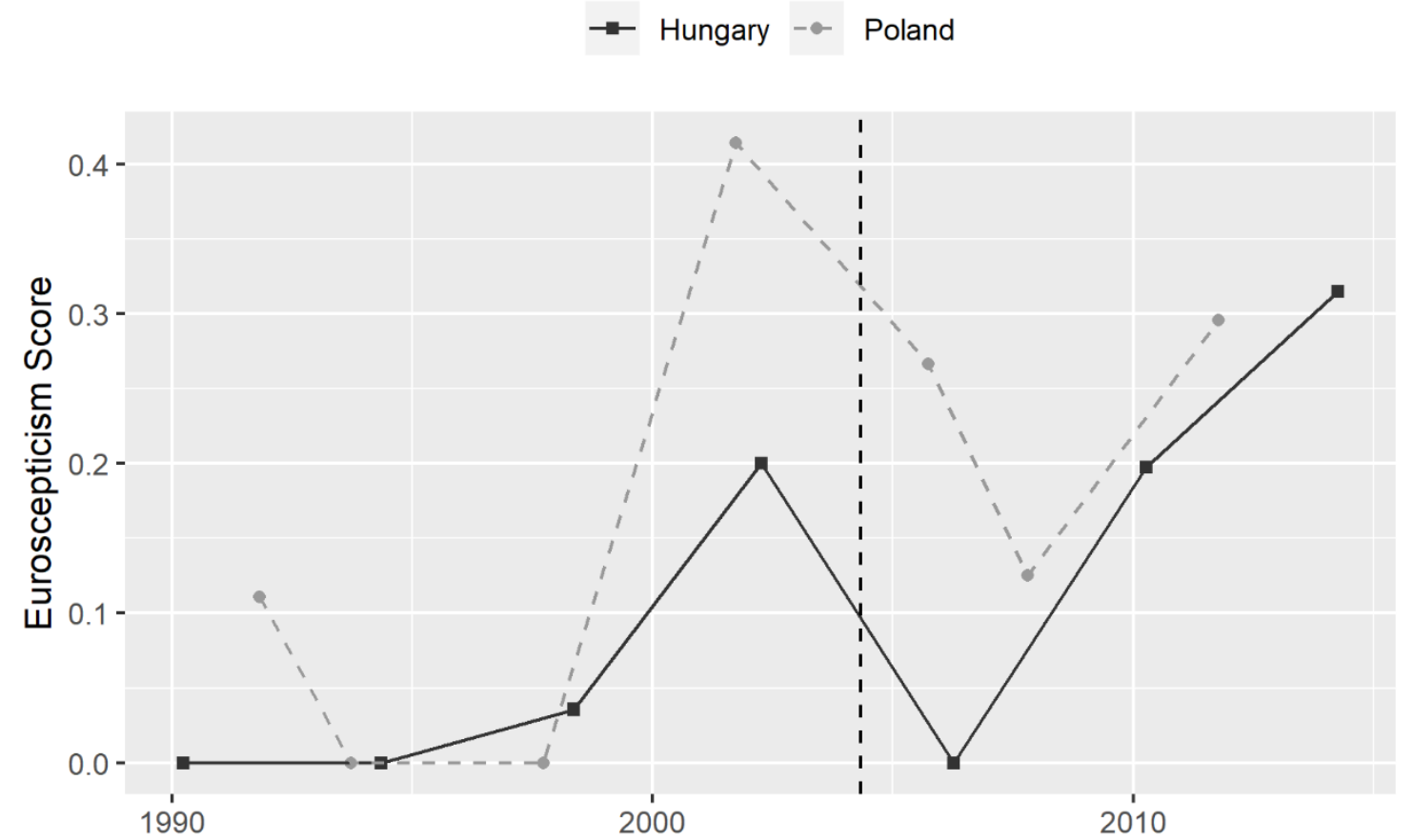

Figure 1. Dynamics of Euroscepticism in party manifestos in Poland and Hungary in 1990-2015.

Notes: The dashed vertical line corresponds to the 2004 EU enlargement. Dots correspond to national elections years and show the share of negative mentions of the EU in party manifestos divided by the total share of mentions of the EU and weighted by vote shares for the respective parties in national elections. 


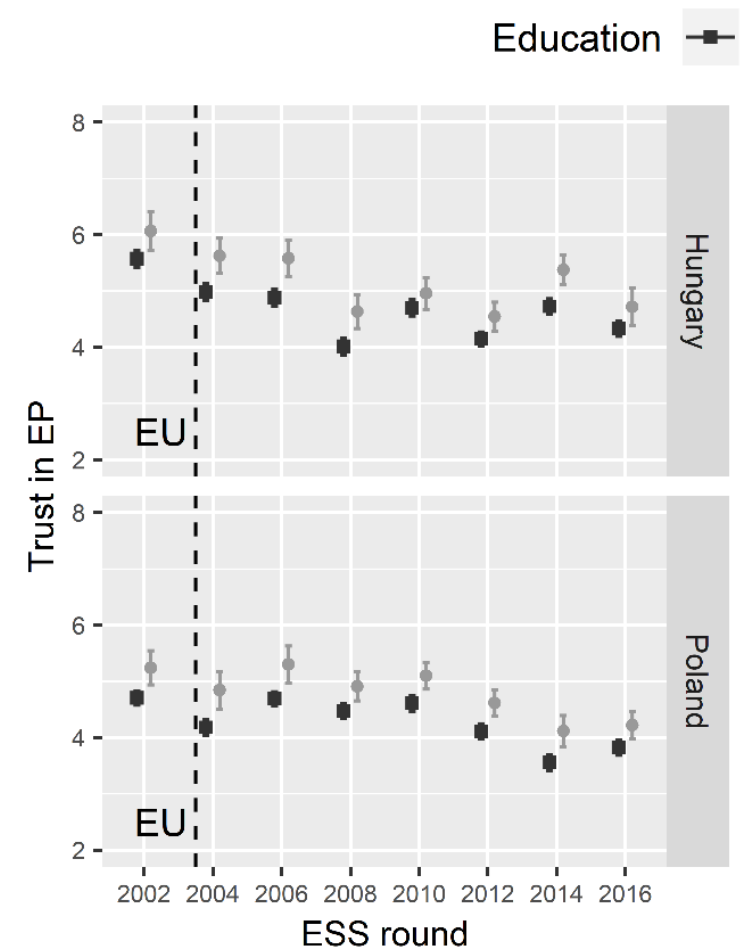

Not $\multimap$ Higher

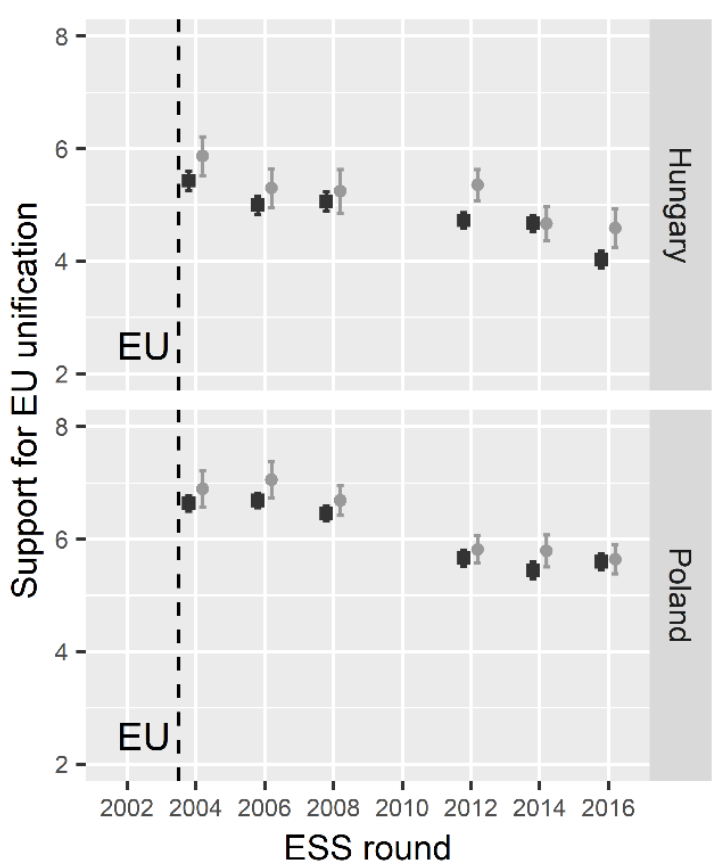

Figure 2. Dynamics of attitudes towards the EU in Hungary and Poland by education status. Source: ESS longitudinal data 2002-2016.

Note: The dashed vertical line corresponds to the 2004 EU enlargement. Dots represent country means for the educated group (grey) and the rest of the sample (black). Confidence bars represent $95 \%$ CIs. 


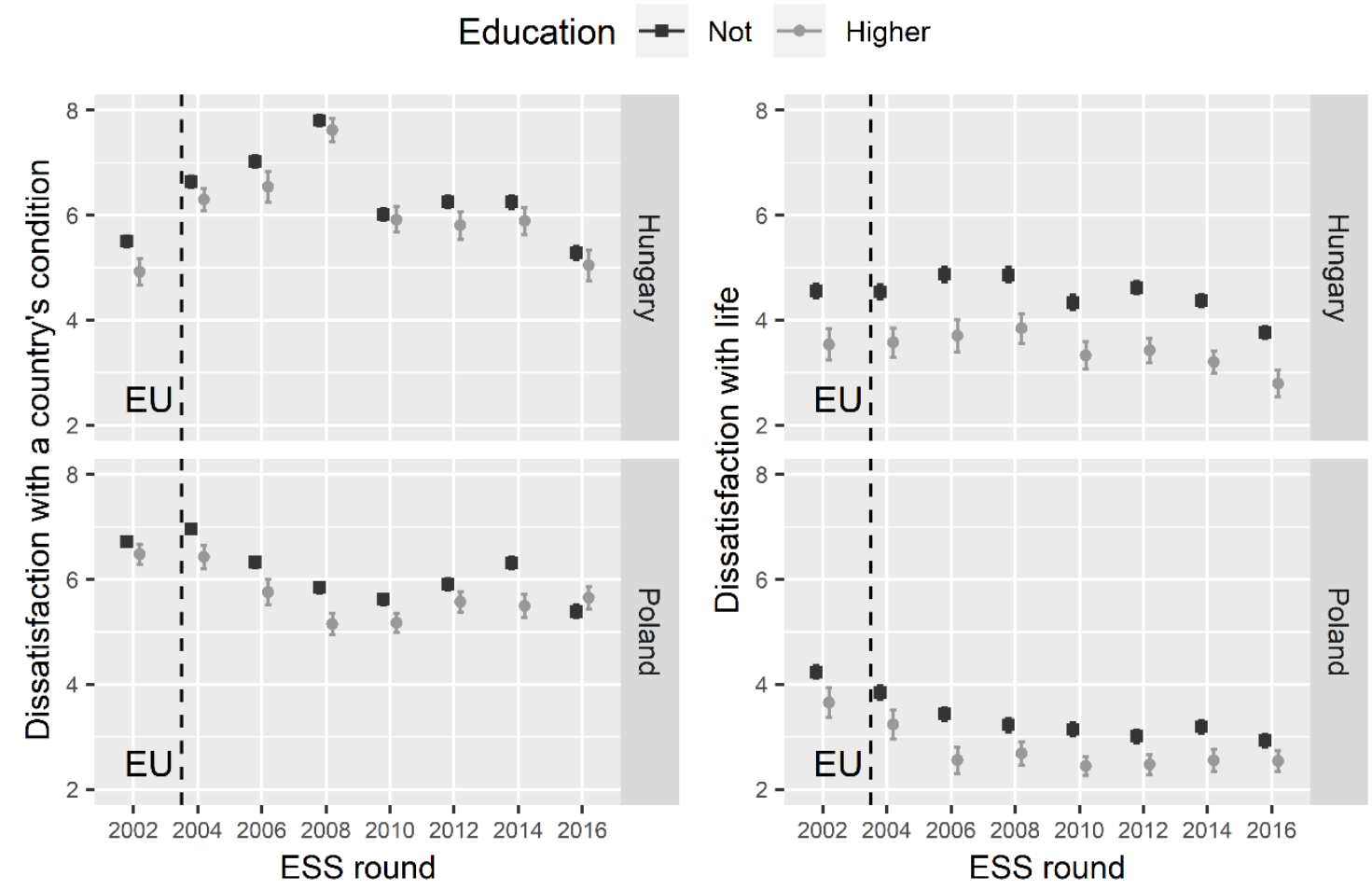

Figure 3. Dynamics of different types of dissatisfaction in Hungary and Poland by education status. Source: ESS longitudinal data 2002-2016.

Note: The dashed vertical line corresponds to the 2004 EU enlargement. Dots represent country means for the educated group (grey) and the rest of the sample (black). Confidence bars represent $95 \%$ CIs. 
Country: Hungary

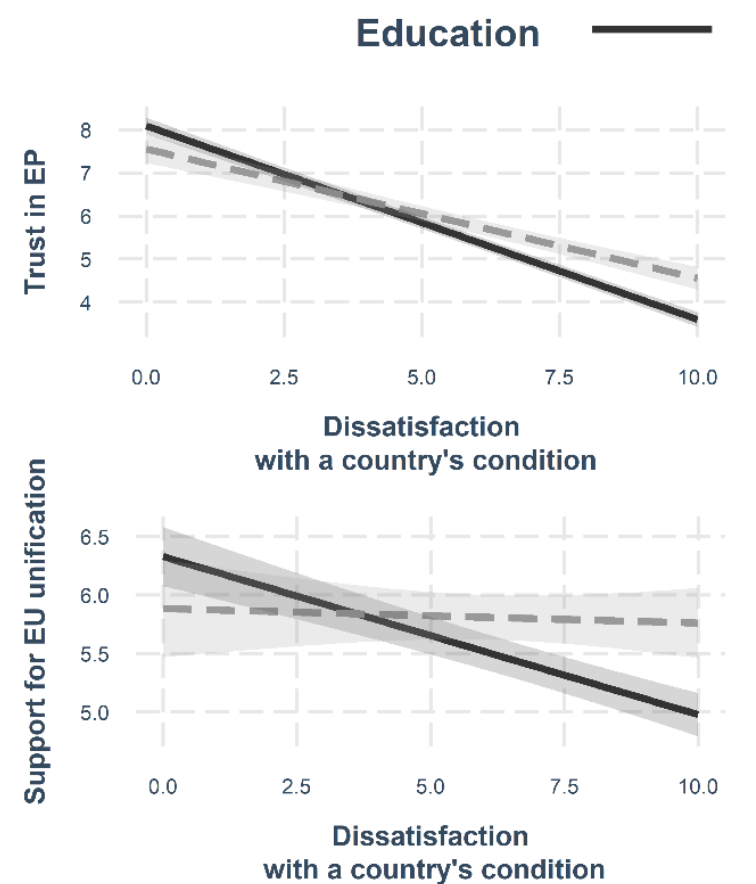

Not $\quad--=$ Higher
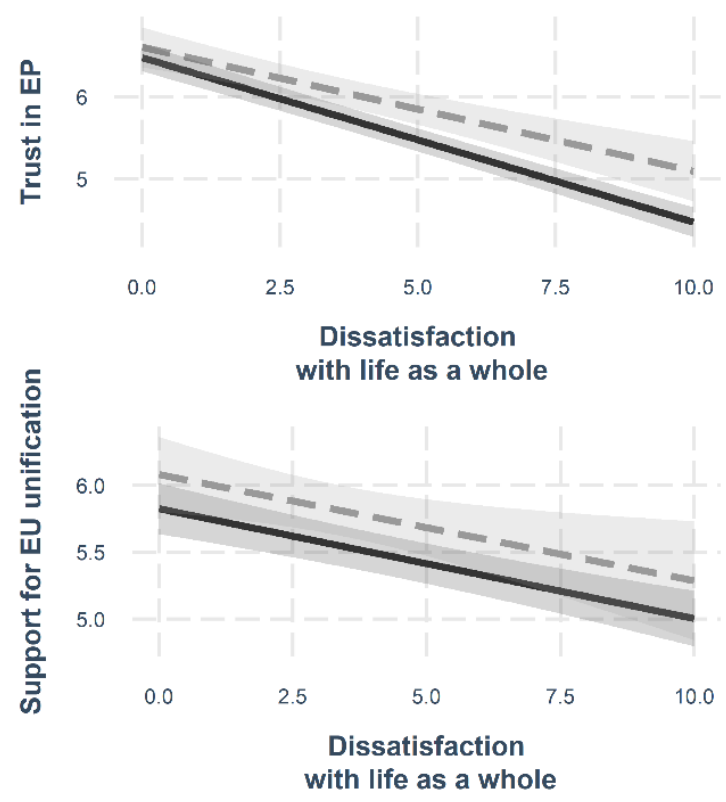

Figure 4. Interaction between different types of dissatisfaction and education status. Country: Hungary.

Source: ESS longitudinal data 2002-2016. 


\section{Country: Poland}

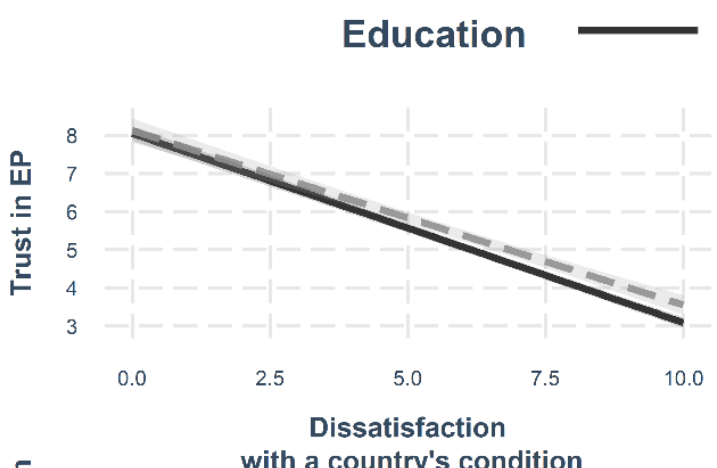

Not $--=$ Higher
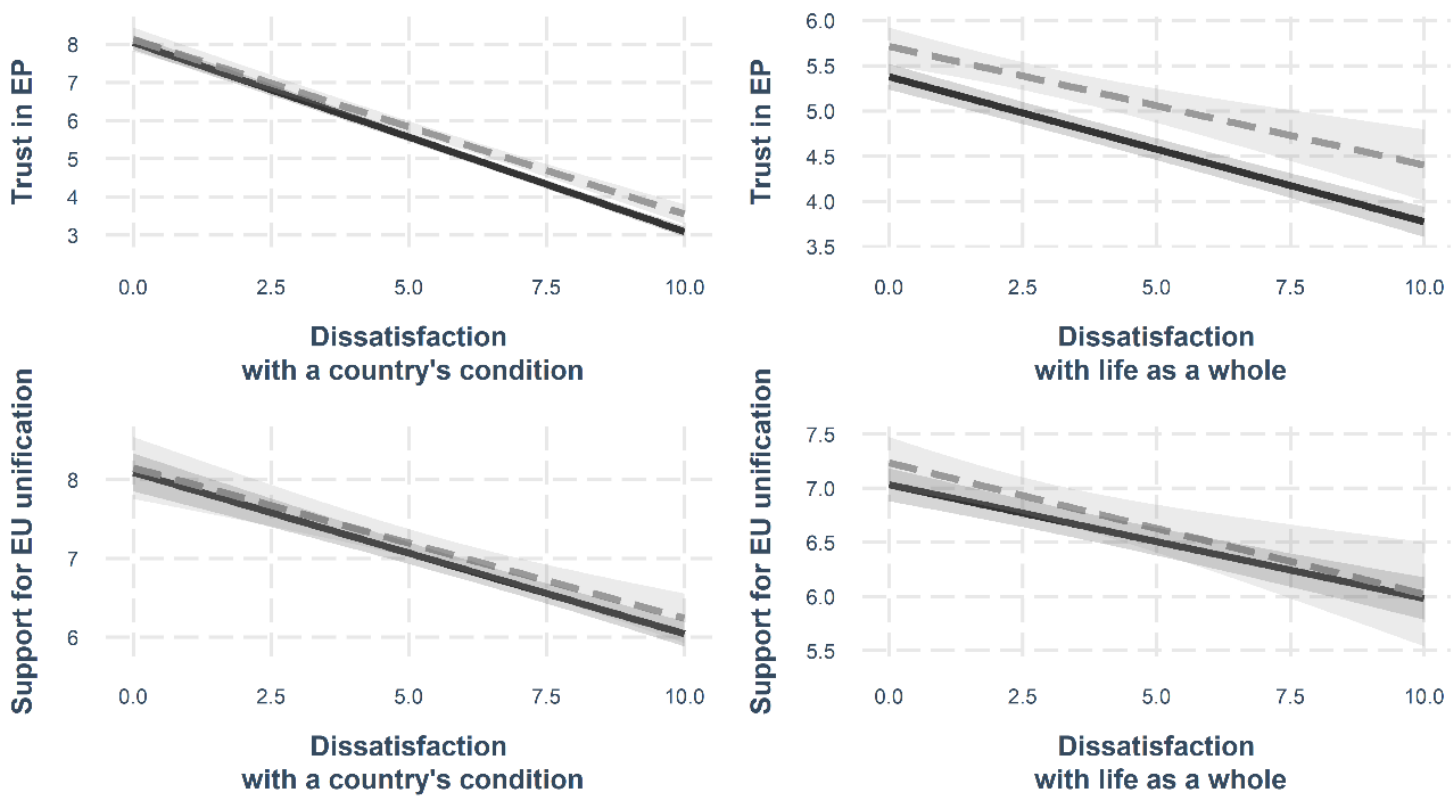

Figure 5. Interaction between different types of dissatisfaction and education status. Country: Poland.

Source: ESS longitudinal data 2002-2016. 


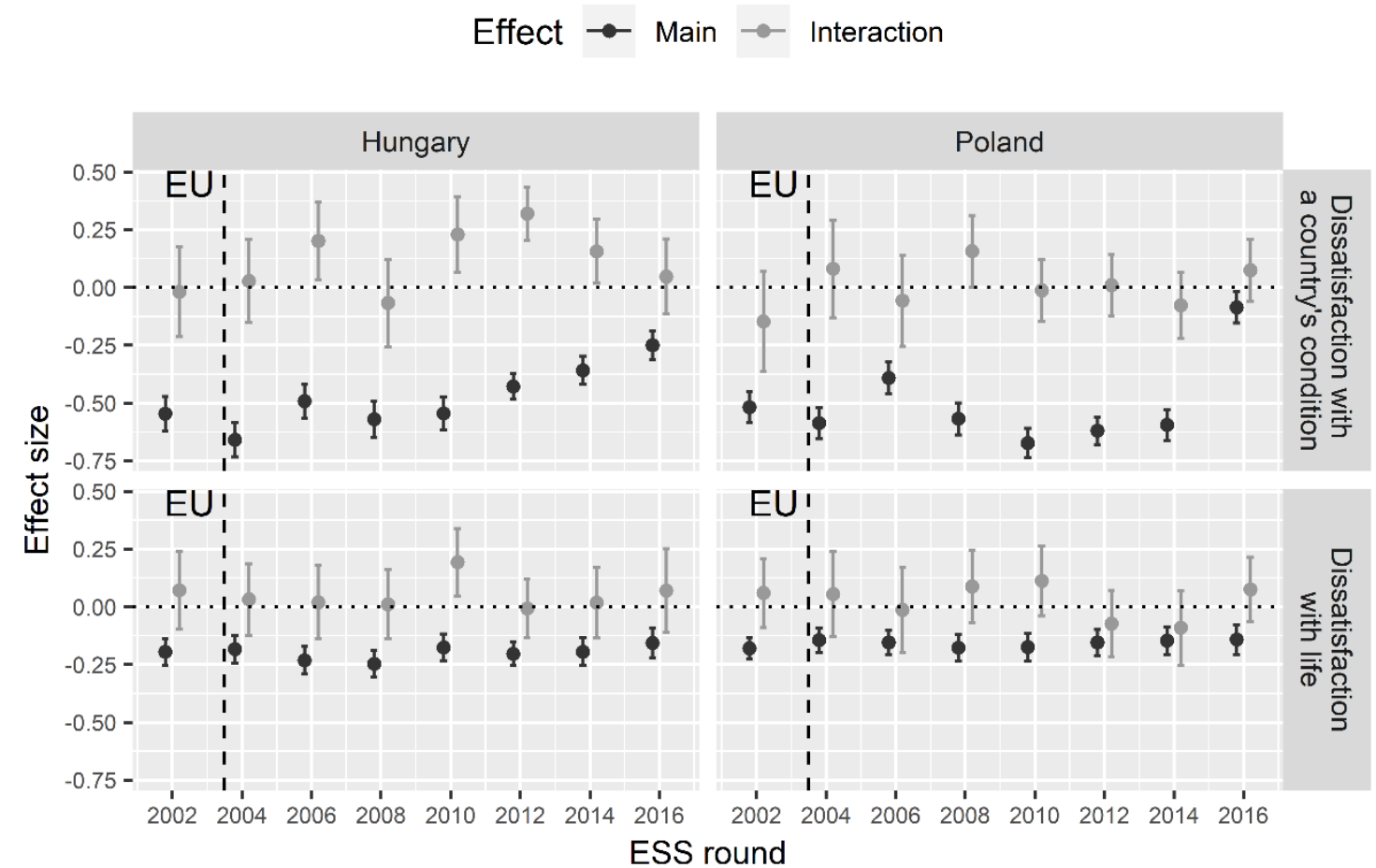

Figure 6. Round-specific effect sizes of various types of dissatisfaction and their interactions with education status. DV: Trust in the European parliament.

Source: ESS longitudinal data 2002-2016.

Note: The dashed vertical line corresponds to the 2004 EU enlargement. Dots represent effect sizes. Confidence bars represent $95 \%$ CIs. 


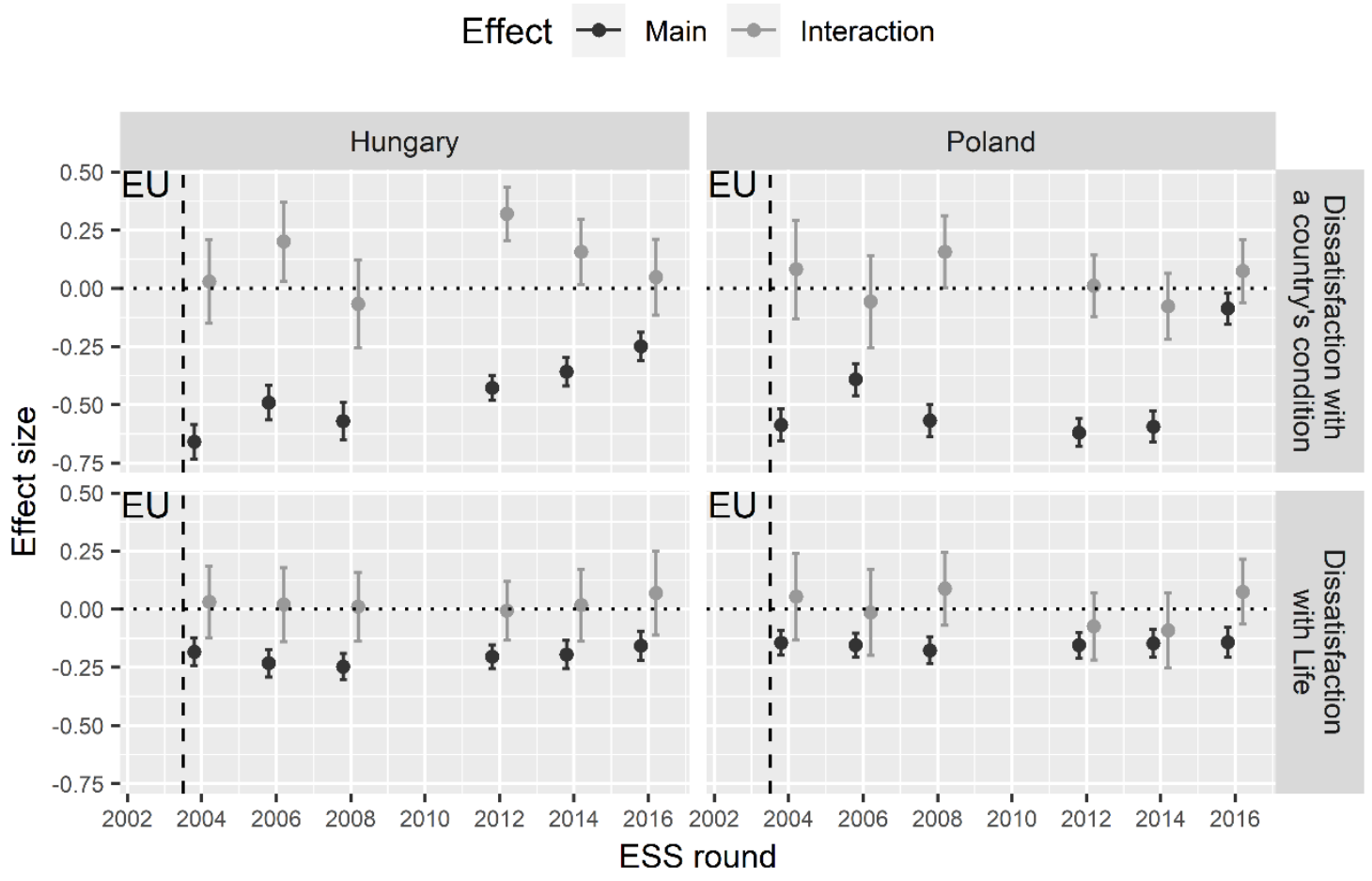

Figure 7. Round-specific effect sizes of various types of dissatisfaction and their interactions with education status. DV: European unification go further or gone too far.

Source: ESS longitudinal data 2002-2016.

Note: The dashed vertical line corresponds to the 2004 EU enlargement. Dots represent effect sizes. Confidence bars represent $95 \%$ CIs. 


\section{Supplemental Information}

Table S1. Descriptive statistics

\begin{tabular}{lccccccc}
\hline Statistic & $\mathrm{N}$ & Mean & St. Dev. & Min & Pctl(25) & Pctl(75) & Max \\
\hline Trust in EP & 23,486 & 4.536 & 2.493 & 0.000 & 3.000 & 6.000 & 10.000 \\
Support for EU unification & 17,641 & 5.524 & 2.691 & 0.000 & 4.000 & 8.000 & 10.000 \\
Dissatisfaction with democracy & 25,581 & 5.650 & 2.434 & 0.000 & 4.000 & 7.000 & 10.000 \\
Dissatisfaction with government & 25,966 & 6.550 & 2.482 & 0.000 & 5.000 & 8.000 & 10.000 \\
Dissatisfaction with economy & 26,212 & 6.308 & 2.242 & 0.000 & 5.000 & 8.000 & 10.000 \\
Dissatisfaction with & 27,066 & 3.784 & 2.477 & 0.000 & 2.000 & 5.000 & 10.000 \\
a country's condition & 24,623 & 6.170 & 2.064 & 0.000 & 4.667 & 7.667 & 10.000 \\
Dissatisfaction with life & 27,130 & 0.168 & 0.374 & 0.000 & 0.000 & 0.000 & 1.000 \\
Higher Education: 0 - No, 1 - Yes & 27,095 & 12.015 & 3.506 & 0.000 & 10.000 & 14.000 & 42.000 \\
Education years & 22,580 & 5.523 & 2.359 & 0.000 & 5.000 & 7.000 & 10.000 \\
Left-Right & 27,254 & 1.540 & 0.498 & 1.000 & 1.000 & 2.000 & 2.000 \\
Gender: 1 - Male 2- Female & 27,228 & 46.479 & 18.708 & 15.000 & 31.000 & 61.000 & 97.000 \\
Age & 27,256 & 0.483 & 0.500 & 0 & 0 & 1 & 1 \\
Paid Work: 0 - No, 1 - Yes & & & & & & &
\end{tabular}


Table S2. Main regression results in tabular form.

\begin{tabular}{|c|c|c|c|c|c|c|c|c|}
\hline & \multicolumn{4}{|c|}{ Trust in the European Parliament } & \multicolumn{4}{|c|}{$\begin{array}{l}\text { European unification go } \\
\text { further or gone too far }\end{array}$} \\
\hline & $\begin{array}{l}\text { Hungary } \\
\text { (1) }\end{array}$ & $\begin{array}{c}\text { Hungary } \\
\text { (2) }\end{array}$ & $\begin{array}{c}\text { Poland } \\
\text { (3) }\end{array}$ & $\begin{array}{l}\text { Poland } \\
\text { (4) }\end{array}$ & $\begin{array}{c}\text { Hungary } \\
\text { (5) }\end{array}$ & $\begin{array}{c}\text { Hungary } \\
\text { (6) }\end{array}$ & $\begin{array}{l}\text { Poland } \\
\text { (7) }\end{array}$ & $\begin{array}{c}\text { Poland } \\
\text { (8) }\end{array}$ \\
\hline $\begin{array}{l}\text { Education: } \\
\text { Higher }\end{array}$ & $\begin{array}{l}-0.537^{* *} \\
(0.173)\end{array}$ & $\begin{array}{c}0.127 \\
(0.115)\end{array}$ & $\begin{array}{c}0.077 \\
(0.165)\end{array}$ & $\begin{array}{l}0.335^{* * *} \\
(0.095)\end{array}$ & $\begin{array}{l}-0.444^{*} \\
(0.222)\end{array}$ & $\begin{array}{c}0.256 \\
(0.142)\end{array}$ & $\begin{array}{c}0.056 \\
(0.210)\end{array}$ & $\begin{array}{c}0.202 \\
(0.113)\end{array}$ \\
\hline $\begin{array}{l}\text { Dissatisfaction } \\
\text { with } \\
\text { a country's } \\
\text { condition }\end{array}$ & $\begin{array}{c}-0.449^{* * *} \\
(0.012)\end{array}$ & & $\begin{array}{c}-0.495^{* * *} \\
(0.012)\end{array}$ & & $\begin{array}{c}-0.135^{* * *} \\
(0.016)\end{array}$ & & $\begin{array}{c}-0.205^{* * *} \\
(0.015)\end{array}$ & \\
\hline $\begin{array}{l}\text { Dissatisfaction } \\
\text { with life }\end{array}$ & & $\begin{array}{l}-0.201^{* * *} \\
(0.010)\end{array}$ & & $\begin{array}{l}-0.160^{* * *} \\
(0.010)\end{array}$ & & $\begin{array}{c}-0.082^{* * *} \\
(0.013)\end{array}$ & & $\begin{array}{c}-0.105^{* * * *} \\
(0.012)\end{array}$ \\
\hline $\begin{array}{l}\text { Education * } \\
\text { Dissatisfaction } \\
\text { with } \\
\text { a country's } \\
\text { condition }\end{array}$ & $\begin{array}{l}0.149^{* * *} \\
(0.027)\end{array}$ & & $\begin{array}{c}0.038 \\
(0.028)\end{array}$ & & $\begin{array}{l}0.123^{* * *} \\
(0.034)\end{array}$ & & $\begin{array}{c}0.014 \\
(0.035)\end{array}$ & \\
\hline $\begin{array}{l}\text { Education * } \\
\text { Dissatisfaction } \\
\text { with Life }\end{array}$ & & $\begin{array}{c}0.050 \\
(0.027)\end{array}$ & & $\begin{array}{c}0.029 \\
(0.028)\end{array}$ & & $\begin{array}{c}0.003 \\
(0.034)\end{array}$ & & $\begin{array}{l}-0.016 \\
(0.034)\end{array}$ \\
\hline Constant & $\begin{array}{l}8.092^{* * *} \\
(0.099)\end{array}$ & $\begin{array}{c}6.479^{* * *} \\
(0.086)\end{array}$ & $\begin{array}{l}8.045^{* * *} \\
(0.098)\end{array}$ & $\begin{array}{l}5.379^{* * *} \\
(0.073)\end{array}$ & $\begin{array}{l}6.329^{* * *} \\
(0.129)\end{array}$ & $\begin{array}{l}5.825^{* * *} \\
(0.097)\end{array}$ & $\begin{array}{c}8.093^{* * *} \\
(0.123)\end{array}$ & $\begin{array}{c}7.031^{* * *} \\
(0.078)\end{array}$ \\
\hline Fixed effects & Yes & Yes & Yes & Yes & Yes & Yes & Yes & Yes \\
\hline Observations & 10,546 & 11,264 & 11,477 & 12,023 & 7,892 & 8,276 & 8,771 & 9,259 \\
\hline Adjusted $\mathrm{R}^{2}$ & 0.159 & 0.072 & 0.175 & 0.053 & 0.037 & 0.033 & 0.067 & 0.050 \\
\hline
\end{tabular}

Note: $\quad$ Entries are unstandardized OLS estimates with standard errors in parentheses. $* \mathrm{p}<0.05 ; * * \mathrm{p}<0.01 ; * * * \mathrm{p}<0.001$ 
Table S3. Replication of the main results with added control variables.

\begin{tabular}{|c|c|c|c|c|c|c|c|c|}
\hline & \multicolumn{4}{|c|}{ Trust in the European Parliament } & \multicolumn{4}{|c|}{$\begin{array}{l}\text { European unification go } \\
\text { further or gone too far }\end{array}$} \\
\hline & $\begin{array}{c}\text { Hungary } \\
\text { (1) }\end{array}$ & $\begin{array}{c}\text { Hungary } \\
\text { (2) }\end{array}$ & $\begin{array}{l}\text { Poland } \\
\text { (3) }\end{array}$ & $\begin{array}{l}\text { Poland } \\
\text { (4) }\end{array}$ & $\begin{array}{c}\text { Hungary } \\
\text { (5) }\end{array}$ & $\begin{array}{c}\text { Hungary } \\
\text { (6) }\end{array}$ & $\begin{array}{c}\text { Poland } \\
\text { (7) }\end{array}$ & $\begin{array}{c}\text { Poland } \\
\text { (8) }\end{array}$ \\
\hline $\begin{array}{l}\text { Education: } \\
\text { Higher }\end{array}$ & $\begin{array}{c}-0.538^{* *} \\
(0.179)\end{array}$ & $\begin{array}{c}0.124 \\
(0.122)\end{array}$ & $\begin{array}{c}0.028 \\
(0.170)\end{array}$ & $\begin{array}{c}0.364^{* * *} \\
(0.099)\end{array}$ & $\begin{array}{l}-0.471^{*} \\
(0.227)\end{array}$ & $\begin{array}{l}0.328^{*} \\
(0.150)\end{array}$ & $\begin{array}{c}0.005 \\
(0.215)\end{array}$ & $\begin{array}{c}0.174 \\
(0.119)\end{array}$ \\
\hline $\begin{array}{l}\text { Dissatisfaction } \\
\text { with } \\
\text { a country's } \\
\text { condition }\end{array}$ & $\begin{array}{c}-0.443^{* * *} \\
(0.013)\end{array}$ & & $\begin{array}{c}-0.491^{* * *} \\
(0.013)\end{array}$ & & $\begin{array}{c}-0.146^{* * * *} \\
(0.016)\end{array}$ & & $\begin{array}{c}-0.219^{* * *} \\
(0.017)\end{array}$ & \\
\hline $\begin{array}{l}\text { Dissatisfaction } \\
\text { with life }\end{array}$ & & $\begin{array}{c}-0.198^{* * *} \\
(0.011)\end{array}$ & & $\begin{array}{c}-0.151^{* * *} \\
(0.011)\end{array}$ & & $\begin{array}{c}-0.075^{* * *} \\
(0.014)\end{array}$ & & $\begin{array}{c}-0.106^{* * *} \\
(0.014)\end{array}$ \\
\hline Left-Right & $\begin{array}{c}-0.056^{* * *} \\
(0.010)\end{array}$ & $\begin{array}{l}-0.024^{*} \\
(0.010)\end{array}$ & $\begin{array}{c}-0.084^{* * *} \\
(0.009)\end{array}$ & $\begin{array}{c}-0.049^{* * *} \\
(0.010)\end{array}$ & $\begin{array}{c}-0.143^{* * *} \\
(0.013)\end{array}$ & $\begin{array}{c}-0.136^{* * *} \\
(0.013)\end{array}$ & $\begin{array}{c}-0.087^{* * *} \\
(0.012)\end{array}$ & $\begin{array}{c}-0.066^{* * *} \\
(0.012)\end{array}$ \\
\hline $\begin{array}{l}\text { Gender: } \\
\text { Female }\end{array}$ & $\begin{array}{c}0.099^{*} \\
(0.048)\end{array}$ & $\begin{array}{l}0.099^{*} \\
(0.050)\end{array}$ & $\begin{array}{l}0.130^{* *} \\
(0.044)\end{array}$ & $\begin{array}{c}0.053 \\
(0.046)\end{array}$ & $\begin{array}{l}-0.052 \\
(0.062)\end{array}$ & $\begin{array}{l}-0.062 \\
(0.062)\end{array}$ & $\begin{array}{c}0.026 \\
(0.056)\end{array}$ & $\begin{array}{c}0.012 \\
(0.056)\end{array}$ \\
\hline Age & $\begin{array}{c}-0.007^{* * *} \\
(0.001)\end{array}$ & $\begin{array}{l}-0.002 \\
(0.001)\end{array}$ & $\begin{array}{c}-0.007^{* * *} \\
(0.001)\end{array}$ & $\begin{array}{c}-0.005^{* * *} \\
(0.001)\end{array}$ & $\begin{array}{c}-0.010^{* * *} \\
(0.002)\end{array}$ & $\begin{array}{c}-0.008^{* * *} \\
(0.002)\end{array}$ & $\begin{array}{c}-0.005^{* *} \\
(0.002)\end{array}$ & $\begin{array}{l}-0.003^{*} \\
(0.002)\end{array}$ \\
\hline $\begin{array}{l}\text { Paid work: } \\
\text { Yes }\end{array}$ & $\begin{array}{c}0.055 \\
(0.052)\end{array}$ & $\begin{array}{l}-0.029 \\
(0.054)\end{array}$ & $\begin{array}{l}-0.064 \\
(0.046)\end{array}$ & $\begin{array}{c}-0.138^{* *} \\
(0.049)\end{array}$ & $\begin{array}{l}-0.093 \\
(0.068)\end{array}$ & $\begin{array}{l}-0.105 \\
(0.067)\end{array}$ & $\begin{array}{c}0.074 \\
(0.060)\end{array}$ & $\begin{array}{c}0.044 \\
(0.059)\end{array}$ \\
\hline $\begin{array}{l}\text { Education * } \\
\text { Dissatisfaction } \\
\text { with } \\
\text { a country's } \\
\text { condition }\end{array}$ & $\begin{array}{c}0.144^{* * *} \\
(0.028)\end{array}$ & & $\begin{array}{c}0.038 \\
(0.028)\end{array}$ & & $\begin{array}{l}0.127^{* * *} \\
(0.035)\end{array}$ & & $\begin{array}{c}0.015 \\
(0.036)\end{array}$ & \\
\hline $\begin{array}{l}\text { Education * } \\
\text { Dissatisfaction } \\
\text { with life }\end{array}$ & & $\begin{array}{c}0.036 \\
(0.029)\end{array}$ & & $\begin{array}{c}0.014 \\
(0.028)\end{array}$ & & $\begin{array}{l}-0.021 \\
(0.036)\end{array}$ & & $\begin{array}{c}-0.014 \\
(0.035)\end{array}$ \\
\hline Constant & $\begin{array}{c}8.540^{* * * *} \\
(0.164)\end{array}$ & $\begin{array}{c}6.641^{* * * *} \\
(0.153)\end{array}$ & $\begin{array}{c}8.613^{* * *} \\
(0.145)\end{array}$ & $\begin{array}{c}5.843^{* * * *} \\
(0.130)\end{array}$ & $\begin{array}{l}7.746^{\text {**** }} \\
(0.216)\end{array}$ & $\begin{array}{l}7.042^{* * * *} \\
(0.190)\end{array}$ & $\begin{array}{c}8.809^{* * *} \\
(0.190)\end{array}$ & $\begin{array}{c}7.551^{* * *} \\
(0.155)\end{array}$ \\
\hline Fixed effects & Yes & Yes & Yes & Yes & Yes & Yes & Yes & Yes \\
\hline Observations & 9,221 & 9,640 & 10,142 & 10,420 & 6,937 & 7,152 & 7,705 & 7,964 \\
\hline Adjusted $\mathrm{R}^{2}$ & 0.156 & 0.072 & 0.177 & 0.055 & 0.057 & 0.050 & 0.074 & 0.055 \\
\hline
\end{tabular}

Note:

Entries are unstandardized OLS estimates with standard errors in parentheses. $* \mathrm{p}<0.05 ; * * \mathrm{p}<0.01 ; * * * \mathrm{p}<0.001$ 

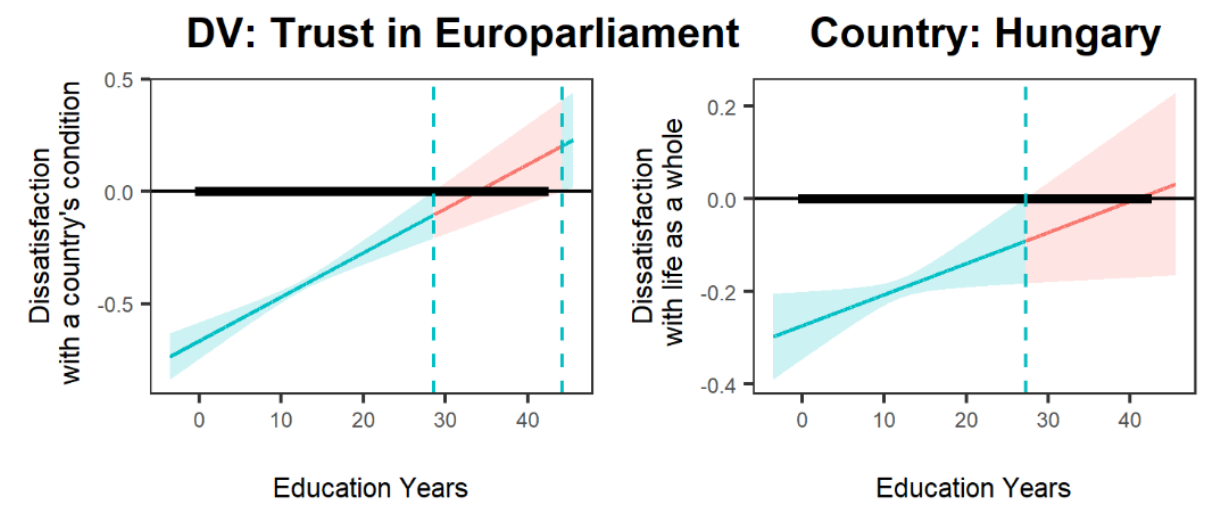

Range of observed
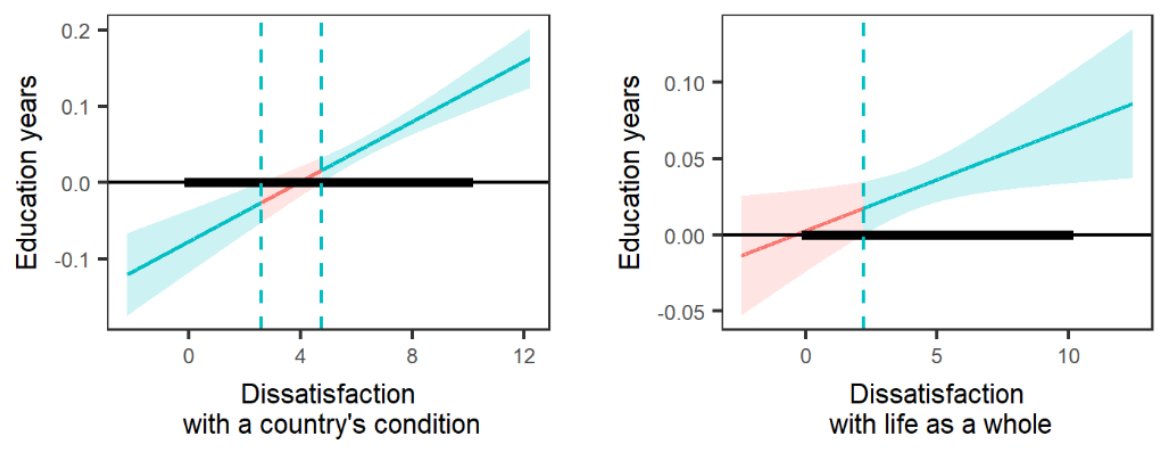

n.s. $p<.05$

Figure S1. Marginal effects of different types of dissatisfaction and years of education. DV: Trust in the European parliament. Country: Hungary.

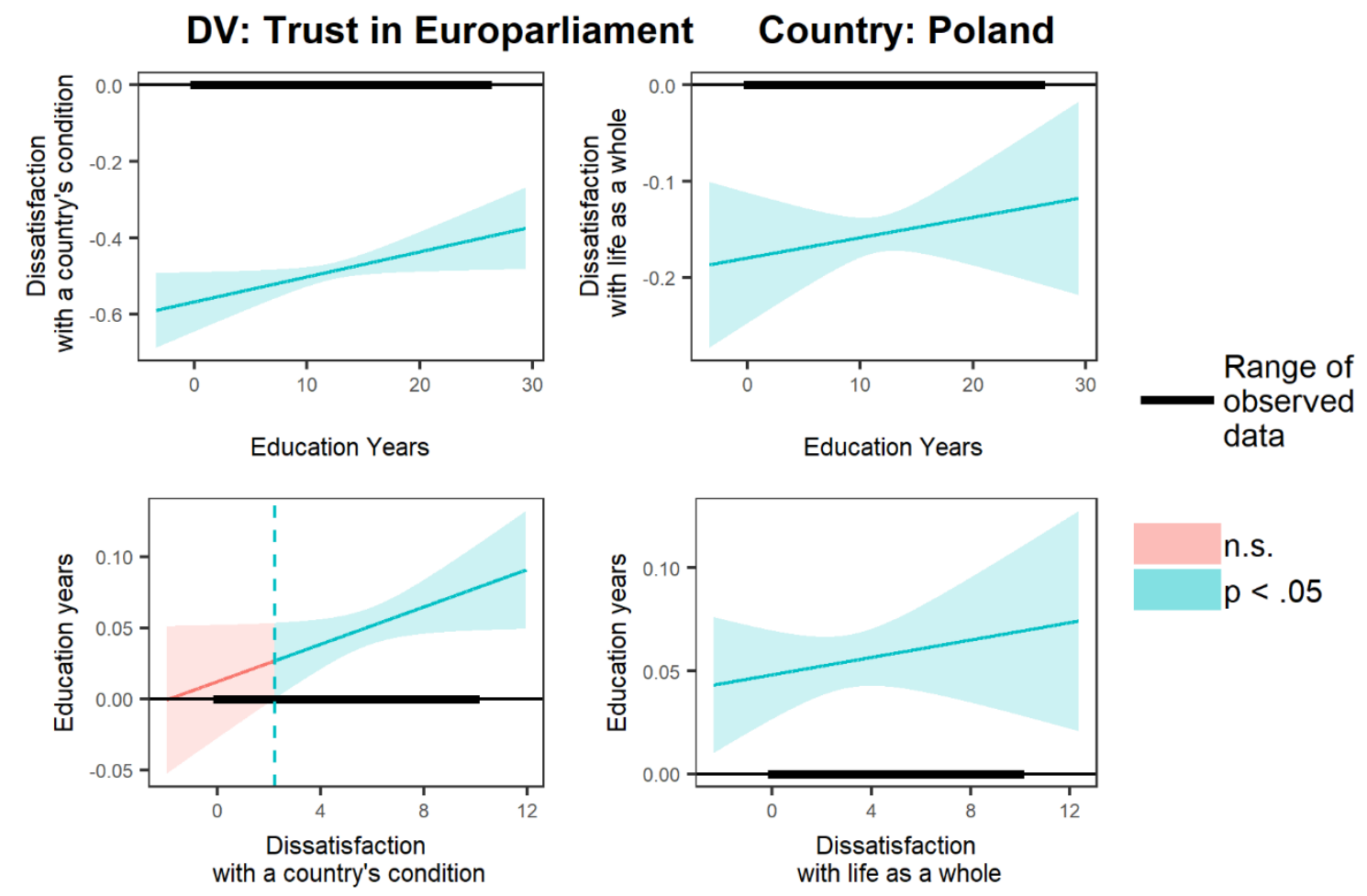

Figure S2. Marginal effects of different types of dissatisfaction and years of education. DV: Trust in the European parliament. Country: Poland. 
DV: Further European Unification Country: Hungary
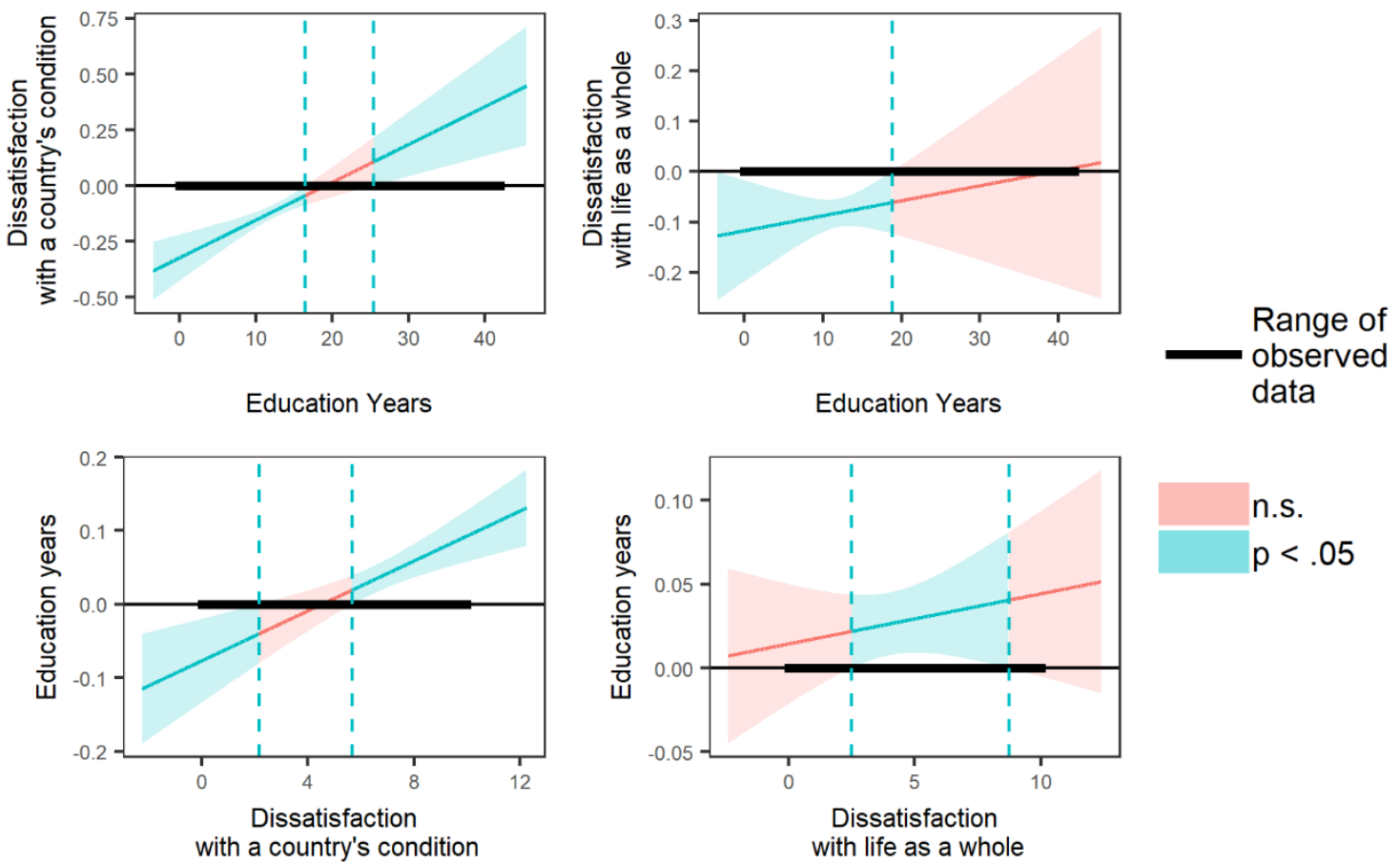

n.s.

$p<.05$

Figure S3. Marginal effects of different types of dissatisfaction and years of education. DV: European unification go further or gone too far. Country: Hungary

\section{DV: Further European Unification Country: Poland}

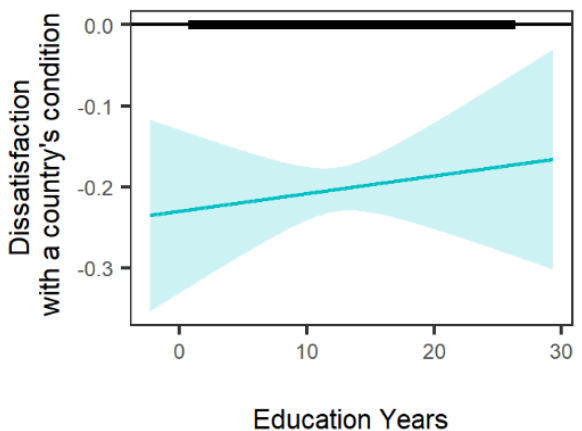

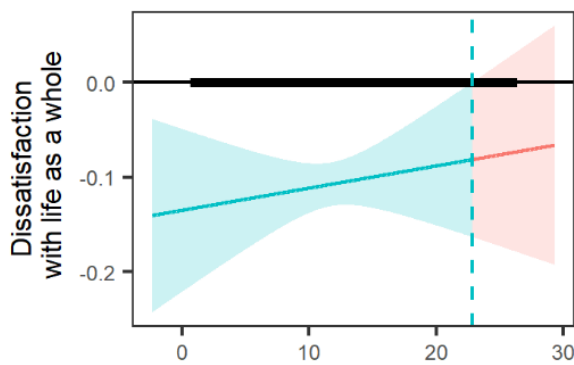

Education Years

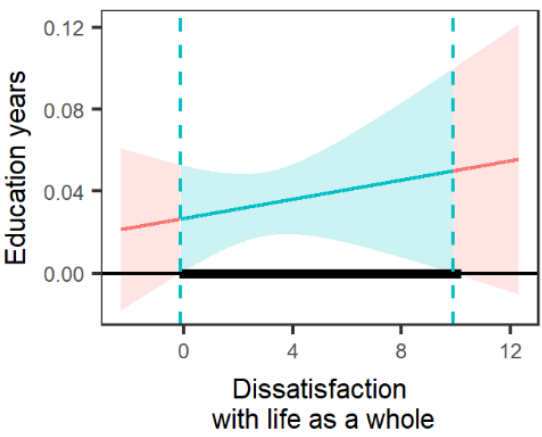

Range of

observed data

n.s.

$p<.05$

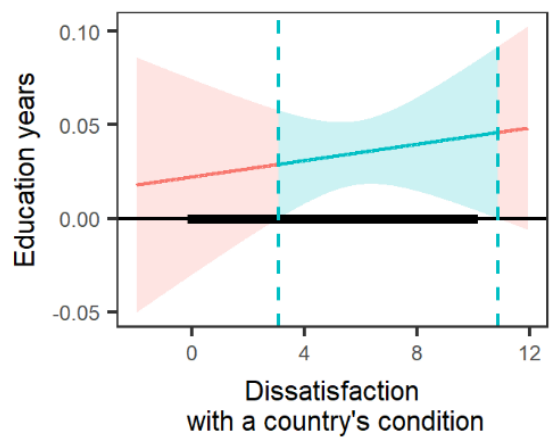

Figure S4. Marginal effects of different types of dissatisfaction and years of education. DV: European unification go further or gone too far. Country: Poland 
Boris Sokolov

National Research University Higher School of Economics

Laboratory for Comparative Social Research, Research Fellow

E-mail: bssokolov@gmail.com, bssokolov@ hse.ru

Eduard Ponarin,

National Research University Higher School of Economics

Laboratory for Comparative Social Research, Laboratory Head,

Tenured Professor

E-mail: ponarin13@gmail.com, eponarin@hse.ru

Any opinions or claims contained in this Working Paper do not necessarily reflect the views of $\mathrm{HSE}$.

(C) Sokolov, Ponarin 2019 